Review

\title{
Reinventing Diagnostics for Personalized Therapy in Oncology
}

\author{
Diponkar Banerjee ${ }^{1,2,3}$
}

1 Centre for Translational and Applied Genomics (CTAG), Provincial Health Services Authority (PHSA) Laboratories, Vancouver, British Columbia, Canada

2 Department of Pathology and Laboratory Medicine, Faculty of Medicine, University of British Columbia, Vancouver, British Columbia, Canada

3 Department of Pathology, British Columbia Cancer Agency (BCCA), 600 West 10th Avenue, Vancouver, British Columbia, V5Z4E6, Canada; E-Mail: dbanerje@bccancer.bc.ca;

Tel.: +1-604-877-6074; Fax: +1-604-877-6017

Received: 6 April 2010; in revised form: 15 May 2010 / Accepted: 28 May 2010 /

Published: 2 June 2010

\begin{abstract}
Human cancers are still diagnosed and classified using the light microscope. The criteria are based upon morphologic observations by pathologists and tend to be subject to interobserver variation. In preoperative biopsies of non-small cell lung cancers, the diagnostic concordance, even amongst experienced pulmonary pathologists, is no better than a coin-toss. Only $25 \%$ of cancer patients, on average, benefit from therapy as most therapies do not account for individual factors that influence response or outcome. Unsuccessful first line therapy costs Canada CAN\$1.2 billion for the top 14 cancer types, and this extrapolates to $\$ 90$ billion globally. The availability of accurate drug selection for personalized therapy could better allocate these precious resources to the right therapies. This wasteful situation is beginning to change with the completion of the human genome sequencing project and with the increasing availability of targeted therapies. Both factors are giving rise to attempts to correlate tumor characteristics and response to specific adjuvant and neoadjuvant therapies. Static cancer classification and grading systems need to be replaced by functional classification systems that not only account for intra- and intertumor heterogeneity, but which also allow for the selection of the correct chemotherapeutic compounds for the individual patient. In this review, the examples of lung and breast cancer are used to illustrate the issues to be addressed in the coming years, as well as the emerging technologies that have great promise in enabling personalized therapy.
\end{abstract}

Keywords: lung; breast; genomics; classification; biomarkers; personalized therapy 


\section{Introduction}

The diagnosis and classification of human cancers by pathologists remains largely based upon microscopic examination of tissue (histopathology) or cells (cytopathology) using brightfield microscopy of chemical dye-stained tissue sections or cytologic preparations. The compound light microscope was invented by Hans Lippershey, Zacharias Janssen, and Hans Janssen in 1590 [1]. Tissue and cellular stains were developed in the mid 1800s. The stains were largely based upon haematoxylin, a naturally occurring chemical derived from the logwood tree, Haematoxylon campechianum. The logwood tree was "discovered" by the Spanish in Campeche in the Yucatan peninsula in 1502, where the locals were already using extracts of the logwood tree for dyeing cotton [2]. To this day pathologists everywhere in the world rely upon haematoxylin and eosin (H\&E) labelled tissue sections to diagnose cancer using a compound light microscope. Diagnostic criteria and current classification systems in clinical use for human cancers remain largely morphology based [3-26], with their attendant problems with interobserver variability [27-45]. Notable exceptions are the classification systems of neoplasms of haematopoietic and lymphopoietic systems, which are now heavily reliant upon ancillary technologies [46]. It would not be too far-fetched to state that, with a few exceptions, we continue to use technology that is between 400 and 500 years old [47].

Since the early days of histology, in a gradual and incremental fashion, additional staining methods were developed to better define tissue components and cellular detail. In the 1960s, the arrival of diagnostic transmission electron microscopy [48] changed some aspects of cancer pathology, only to be largely supplanted by immunohistochemistry and molecular diagnostics. The latter two were due to the invention of monoclonal antibody technology by Kohler and Milstein in 1975 [49], and the polymerase chain reaction by Kary Mullis in 1986 [50], respectively. These two inventions accelerated the rate of change in how ancillary methods were introduced in clinical laboratories, a chain reaction in itself. The availability of monoclonal antibodies against lineage-specific antigens expressed in haematopoietic cells and the invention, in the 1960's, of fluorescence activated cell sorting and flow cytometry by Herzenberg [51] changed the way we diagnose leukemias and lymphomas. However, morphology still plays a major role in diagnosis of these diseases. The successful completion of the human genome sequencing project [52] has now spawned many approaches to try and understand what is awry in human cancers.

\section{The Financial Imperative for Personalized Therapy}

Canada has the second highest public expenditure on pharmaceuticals per capita amongst OECD countries (Table 1). Drug spending in this country is estimated to have reached CAN\$29.8 billion in 2008, representing $17.4 \%$ of the total health expenditure [53]. Spending on pharmaceuticals has more than doubled over the past 10 years. Its growth is faster than that of healthcare costs generated by hospitals, physicians, and other health professionals. Unfortunately, matching the right therapy to the individual patient is not easy and tends to be a trial and error approach. The outcome of individual patients is unpredictable because the probabilities are based upon averages. The possibility of over- or under- treatment exists, with consequences including unnecessary toxicity or denial of more efficacious therapies. It is estimated that between $25 \%$ and $80 \%$ of drugs used to treat various chronic 
diseases have clinical efficacy, with oncology dugs being in the lowest efficacy group at 25\% [54]. I have estimated the direct costs of treating the top 14 cancers in Canada and ranked these by the cost of treating cancers that fail to respond, based upon crude five year mortality rates (Table 2). These costs include standard courses of radiation therapy and chemotherapy, but not surgical costs, costs of second or third line therapy, or indirect costs associated with morbidity and hospitalization. While this may not be sophisticated health economics analysis, it provides a snap shot of the costs of ineffective therapies in Canada every year, supported by the tax-paying citizens of this country. This represents CAN\$1.2 billion dollars being spent on therapies that do not work on individual patients. Imagine a new paradigm that allows personalized therapy, which could redirect CAN\$1.2 billion of wasted resources towards matching the right therapy to the right patient without adding to the annual expenditures of a cash-strapped publicly funded healthcare system. Extrapolating this to the global cancer burden (10.9 million new cases per year in 2002) [55] would mean wasted resources of CAN $\$ 90$ billion per year if all countries followed current standard therapies for the top 14 cancers.

In this review, I summarize the most recent literature on understanding human cancers by using genomic tools. I describe how genomics information is beginning to change our thinking about classification systems, and prognostic and predictive factors. I make a case for the need to incorporate genomics technology into the clinical laboratory. I discuss the limitations of fixed morphologic classification systems and argue for the development of functional classification systems that account for the individual variation and plasticity of cancer stem cells by using lung and breast cancer cells as examples.

Table 1. Ranking of OECD countries by spending (in US dollars) on pharmaceuticals per capita (from OECD Health Data 2009, November 2009) (http://www.oecd.org/document/ 16/0,3343,en_2649_34631_2085200_1_1_1_1,00.html).

\begin{tabular}{llccc}
\hline Rank & OECD Country & Public $\$$ per capita & Total \$ per capita & Percentage public \\
\hline 1 & United States & 307 & 1,015 & 30.2 \\
$\mathbf{2}$ & Canada & $\mathbf{3 0 2}$ & $\mathbf{7 7 0}$ & $\mathbf{3 9 . 2}$ \\
3 & Belgium & 353 & 703 & 50.1 \\
4 & France & 472 & 679 & 69.4 \\
5 & Spain & 464 & 642 & 72.3 \\
6 & Japan & 436 & 609 & 71.7 \\
7 & Germany & 447 & 602 & 74.3 \\
\hline
\end{tabular}

Table 2. Cancer Incidence in Canada in 2009, Ranked by Cost of Treatment Failure (in Canadian dollars) per year.

\begin{tabular}{llcccccc}
\hline \multicolumn{1}{c}{ Cancer } & Total & $\begin{array}{c}\text { Per case } \\
\text { cost }\end{array}$ & $\begin{array}{c}\text { Annual Canadian } \\
\text { Costs }^{\text {a }}\end{array}$ & $\begin{array}{c}\text { Crude 5 year } \\
\text { Survival rates (\%) }\end{array}$ & $\begin{array}{c}\text { Mortality at } \\
\text { 5 years (\%) }\end{array}$ & $\begin{array}{c}\text { Cost of } \\
\text { treatment failure }\end{array}$ \\
\hline 1 & Lung & 23,400 & $\$ 27,295$ & $\$ 638,703,000$ & 14 & 86 & $\$ 549,284,580$ \\
2 & Colorectal & 22,000 & $\$ 26,742$ & $\$ 588,324,000$ & 66 & 34 & $\$ 200,030,160$ \\
3 & Pancreas & 3,900 & $\$ 29,395$ & $\$ 114,640,500$ & 7 & 93 & $\$ 106,615,665$ \\
4 & Lymphoma & 7,200 & $\$ 23,759$ & $\$ 171,064,800$ & 57 & 43 & $\$ 73,557,864$ \\
5 & Ovary & 2,500 & $\$ 40,666$ & $\$ 101,665,000$ & 41 & 59 & $\$ 59,982,350$ \\
6 & Leukemia & 4,700 & $\$ 19,891$ & $\$ 93,487,700$ & 57 & 43 & $\$ 40,199,711$ \\
7 & Kidney & 4,600 & $\$ 27,958$ & $\$ 128,606,800$ & 60 & 40 & $\$ 51,442,720$ \\
\hline
\end{tabular}


Table 2. Cont.

\begin{tabular}{|c|c|c|c|c|c|c|c|}
\hline 8 & Head/Neck* & 9,250 & $\$ 19,891$ & $\$ 183,991,750$ & 74 & 26 & $\$ 47,837,855$ \\
\hline 9 & Breast & 22,900 & $\$ 12,156$ & $\$ 278,372,400$ & 89 & 11 & $\$ 30,620,964$ \\
\hline 10 & Bladder & 6,900 & $\$ 13,592$ & $\$ 93,784,800$ & 80 & 20 & $\$ 18,756,960$ \\
\hline & Prostate & 25,500 & $\$ 12,156$ & $\$ 309,978,000$ & 96 & 4 & $\$ 12,399,120$ \\
\hline 12 & Endometrial & 4,400 & $\$ 17,902$ & $\$ 78,768,800$ & 87 & 13 & $\$ 10,239,944$ \\
\hline & Cervix & 1,300 & $\$ 22,212$ & $\$ 28,875,600$ & 78 & 22 & $\$ 6,352,632$ \\
\hline & Melanoma & 5,000 & $\$ 5,304$ & $\$ 26,520,000$ & 94 & 6 & $\$ 1,591,200$ \\
\hline \multicolumn{7}{|c|}{ Total Cost of treatment failure } & $\$ 1,208,911,725$ \\
\hline \multicolumn{7}{|c|}{ Top 5 cancers } & $\$ 989,470,619$ \\
\hline \multicolumn{7}{|c|}{ Top 10 cancers } & $\$ 1,178,328,829$ \\
\hline
\end{tabular}

${ }^{a}$ Based on extrapolation from US National Cancer treatment costs, converted to CAN\$;

* Includes oral, thyroid and larynx.

\section{Lung Cancer}

Lung cancer is the most common cause of cancer-related mortality affecting men and women. The World Health Organization estimated that in 2004, 1.3 million deaths occurred globally due to lung cancer [56]. In the United States of America, an estimated 219,440 new cases were diagnosed, and 159,390 deaths due to lung cancer were expected in 2009 [57].

Generally, pathologists have attempted to use morphology and immunohistochemistry to broadly categorize lung cancer into small cell carcinoma (SCLC), and non-small cell lung cancer (NSCLC). The latter includes adenocarcinoma (ADC), squamous cell carcinoma (SCC), and large cell carcinoma (LCC) subtypes [58]. The LCC category has been further subdivided into sarcomatoid, lymphoepithelial, clear-cell, rhabdoid, basaloid, and large cell neuroendocrine carcinoma subtypes [59]. Unfortunately, even experienced pathologists with an interest in lung cancer cannot agree on the identification of NSCLC subtypes in preoperative samples, with an accuracy of $55 \%$ or less, depending upon the publication $[60,61]$. This is essentially no better than a coin-toss. Histology does not predict outcomes in NSCLC treated with combined vinorelbine or gemcitabine and cisplatin regimens [62]. This is not surprising, given the lack of agreement amongst expert pathologists. However, other publications and meta-analysis of previously published studies suggest that histological subtyping of NSCLC can predict responses to modern chemotherapeutic agents $[58,63]$. This has led to attempts to better define subsets of NSCLC by using immunohistochemically defined biomarkers, gene expression signatures, gene copy number variation, mutation analysis of growth factor receptor genes, and microRNA profiling.

\subsection{Immunohistochemistry in NSCLC}

Subtyping of NSCLC using immunohistochemistry involves the use of antibodies directed against thyroid transcription factor-1 (TTF-1), p63, CK7, and high molecular weight cytokeratins (HMWCK) [58]. The problem is that no single marker reliably excludes or includes a subtype as a possibility. A combination matrix of biomarkers increases the probability of correctly classifying a given tumor. A recurrent problem with attempts to define biomarkers for cancer classification is that biomarkers are invariably judged against standard morphologic criteria, which as I have already discussed, are inadequate. Although TTF-1 is expressed predominantly in lung adenocarcinomas, it is also expressed 
in $5 \%$ to $21 \%$ of squamous cell carcinomas [64,65]. P63 is expressed in $97 \%$ of SCC, $30 \%$ of adenocarcinomas, $50 \%$ of large cell neuroendocrine carcinomas, and $77 \%$ of small cell carcinomas [66].

Another protein, desmocollin-3, a desmosome associated protein, is expressed in about $50 \%$ of undifferentiated large-cell lung cancers, $100 \%$ of basaloid carcinomas, and almost $60 \%$ of clear-cell carcinomas, but is not expressed in sarcomatoid carcinomas [67].

\subsection{Gene Expression Profiling in NSCLC}

Molecular profiling was able to correctly classify a small group of patients with NSCLC on the basis of relapse $v s$. relapse-free survival [68]. However, these genes were not significant in an RT-PCR validation study [69]. A 31 gene signature is able to correctly predict lymph node metastasis in $85 \%$ of NSCLC patients [70]. A "metagene" model has been developed to predict recurrence of stage IA NSCLC. Univariate and multivariate analyses showed that the model predicted recurrence significantly better than stage, tumor diameter, nodal status, age, sex, histologic subtype, or smoking history, with an overall predictive accuracy of 79 percent [71].

Mitotic kinesin KIF14 is an independent prognostic factor for disease-free survival, including stage, differentiation, and histology in multivariate analysis [72]. Another 35-gene signature stratified patients with NSCLC at stage 1A into distinct prognostic subgroups, and overexpression of the encoded proteins of 2 of the genes, TAL2 (T-cell acute lymphocytic leukemia 2) and ILF3 (interleukin enhancer binding factor 3), was detected in the tumors [73].

\subsection{SAGE Transcriptome Profiles in Carcinoma-in-Situ and Invasive NSCLC}

Lonergan and others reported the first large scale transcriptomic profiling of carcinoma-in-situ (CIS) of the lung, invasive squamous cell carcinoma (SCC), and precancerous (PC) metaplastic and dysplastic epithelia. They identified genes associated with epidermal development and xenobiotic metabolism/detoxification in CIS lesions, genes associated with the immune response, and genes linked with tissue remodeling/fibrosis in SCC. In addition, they observed down-regulation of genes associated with mucociliary differentiation in CIS and PC lesions [74].

\subsection{Gene Copy Number Variation}

A number of genes with copy number increases or overexpression of their encoded proteins, or both, are prognostically significant in NSCLC. Skp2 copy number increase is seen predominantly in SCC, with either gains or losses in ADC. Skp2 protein overexpression, but not skp2 copy number, accompanied by ras mutations, is associated with poor prognosis [75].

Telomerase gene hTERT mRNA overexpression is more frequent in SCC than in ADC, and is associated with $h T E R T$ amplification in ADC. HTERT amplification is an independent prognostic marker for shorter recurrence-free survival in ADC [76].

Although MET amplification is relatively uncommon, it is detected more often in SCC than in $\mathrm{ADC}$, and predicts worse survival in SCC in multivariate analysis [77].

A controversial area is the correlation between EGFR copy number in NSCLC and response to tyrosine kinase inhibitors (TKIs), such as erlotinib and gefitinib. Patients with EGFR copy number 
gains have higher overall response rates than those without gains in placebo-controlled trials of TKIs. $E G F R$ copy number has been claimed to be a stronger predictor of response than EGFR mutation status $[78,79]$. On the other hand, a meta-analysis of over 200 published studies showed that $E G F R$ mutations are more predictive of response to single-agent epidermal growth factor receptor TKIs in advanced NSCLC than EGFR copy number gains. This correlation was seen predominantly in whites and less so amongst Asians [80].

\subsection{Mutation of Tyrosine Kinase Domains in the Epidermal Growth Factor Receptor (EGFR) Gene}

Acquired activating mutations in the tyrosine kinase domain encoding region of EGFR have been identified in lung cancer. It is claimed that these mutations can be used to predict responsiveness to tyrosine kinase inhibitors (TKIs), such as gefitinib and erlotinib [81-83]. Such mutations are more frequently associated with adenocarcinoma (especially of the bronchioloalveolar type), females, Asians, and patients who have never smoked [81]. However, these early studies had no control group. Therefore, there was concern whether the association of activating mutations within the EGFR TK domain with histology, gender, ethnic origin, and "never smoked" status was responsible for the response to TKIs, rather than for the mutation status itself. In fact, when tumors from patients in a clinical trial of erlotinib versus placebo were tested for EGFR mutations, expression, and gene copy number, multivariate analysis showed that the expression of EGFR protein, but not mutation status or copy number, was associated with response. Survival after treatment was not predicted by the status of EGFR expression, the EGFR gene copy number, or mutation status [78]. The story gets more complicated as other studies showed that $10 \%$ of cases without activating EGFR mutations respond to TKIs [84]. TKI therapy, however, may be detrimental to unselected patients not stratified by mutational analysis [85].

\subsection{MicroRNAs in Typing of NSCLC}

MicroRNAs (miRNA) are short non-coding RNA genes that regulate gene expression by either translational down-regulation or by degradation of target mRNA [86]. When miRNAs hsa-miR-205, hsa-miR-21, and U6 snRNA were measured by quantitative reverse transcription-PCR in SCC and NSCLC, a formula based upon average cycle thresholds $\left(\mathrm{C}_{\mathrm{T}}\right)$ could accurately distinguish between SCC and NSCLC, even in pre-resection biopsies [87].

Human serum contains circulating miRNAs. Genome-wide serum miRNA screening was used to determine a serum miRNA signature that correlates with survival. The levels of miR-486, miR-30d, miR-1, and miR-499 were found to be significantly associated with overall survival [88]. The combined detection of microRNAs miR-21, miR-486, miR-375, and miR-200b was able to correctly distinguish between sputum samples from lung adenocarcinoma patients and normal subjects with $80.6 \%$ sensitivity and $91.7 \%$ specificity [89]. It is likely that miRNAs will be widely used for both diagnosis and prognosis in the future. 


\section{Breast Cancer}

\subsection{Gene Expression Profiling}

The current methods of assessing breast cancer tissues are largely morphology based and only a small set of biomarkers consisting of estrogen receptors (ER), progesterone receptors (PR), Her2neu protein or HER2neu gene amplification, and to limited extent, Ki-67, a marker of cell proliferation, are in routine clinical use.

The early excitement around transcriptome profiling or gene expression profiling of breast cancer [90-102] has dissipated somewhat, due to concerns that predictive gene signatures may be only slightly more useful than morphology, hormone receptor status, Her2neu status, and proliferation rates. The field is still controversial, as reproducibility of gene expression data has been less than satisfactory. This is true even for the reanalysis of published data sets, let alone the data from the same analytic platforms to study different sets of tumors from different groups of patients by different groups of investigators [103-107].

There are a number of lessons learned from earlier gene expression studies. One is that each patient's tumor profile is somewhat unique, such that profiles for two different tumor samples from the same patient are more alike than either is to any other patient's breast cancer sample [90]. The second is that this individual "molecular portrait" is remarkably stable over time, even after exposure to chemotherapy [90].

Despite the observation of individual heterogeneity in gene signature patterns, it is possible to group the gene expression profiles into biological clusters. The largest is the proliferation cluster which correlates with the mitotic rate, an important parameter used in the Nottingham score grading system [108] for breast cancer. This cluster includes the genes encoding Ki-67 and PCNA, which are commonly used immunohistochemical markers for proliferating cells. The other clusters, with good correlation with immunohistochemistry (IHC) biomarker test results, include estrogen receptor pathway gene expression levels, and Her2neu. Five subtypes were defined using hierarchical clustering-luminal subtypes A and B, normal breast-like, ERBB2+, and basal-like [92].

Immunohistochemistry, using a simple panel of antibodies, can reproduce the molecular subtyping of breast cancers $[109,110]$. Torsten Nielsen and others have demonstrated that the luminal A and B subtypes are characterized by ER positivity [110]. The ERBB2+ type characterized by Her2neu protein overexpression or Her2neu gene amplification can be easily recognized using IHC and fluorescence in situ hybridization (FISH) methods, respectively. The basal-like type can also be identified by immunohistochemistry, as this subtype is negative for estrogen receptor and HER2, but positive for basal cytokeratins, HER1, and/or c-KIT. They studied 930 patients with 17 years mean follow-up, and found that basal cytokeratin expression was associated with low disease-specific survival. HER 1 expression was observed in $54 \%$ of cases positive for basal cytokeratins (versus $11 \%$ of negative cases). Such cases were associated with poor survival, independent of nodal status and tumor size. C-KIT expression was more common in basal-like tumors than in other types of breast cancers, but had no prognostic value [110]. They later reported that in basal-like breast cancers, a small heat shock protein, alpha-basic-crystallin (alphaB-crystallin), was commonly expressed and associated, independent of other prognostic markers [111], with poor survival in breast cancer patients. The same 
group has been able to distinguish between luminal A and B subtypes by IHC, and has compared those classified by gene expression profiling and IHC by using ER, PR, Ki-67, and Her2neu labelling. The Ki67 index cut point to distinguish luminal B from luminal A tumors was 13.25\%. Luminal B and luminal-HER2-positive breast cancers were associated with poor breast cancer recurrence-free and disease-specific survival in every adjuvant systemic treatment category. Of great interest was the observation that for women who received tamoxifen as their only adjuvant systemic therapy, the 10 -year breast cancer-specific survival was $79 \%$ for luminal A, $64 \%$ for luminal $\mathrm{B}$, and $57 \%$ for luminal-HER2 subtypes [112]. Seven molecular subtypes of breast cancer have been described with different clinical behaviors [113].

\subsection{Gene Expression Profiling and Response to Neoadjuvant Therapies}

In the neoadjuvant setting, predicting response by gene expression profiling has been controversial. In an early study, 10 patients (20 samples) who were to receive neoadjuvant chemotherapy had fine needle aspiration (FNA) biopsies done for gene expression profiling. Three pre-treatment FNA samples out of the 20 yielded an insufficient percentage of tumor cells for analysis. Thirty-seven genes distinguishing between good and poor responders were identified, including genes involved in cell death and chemosensitivity [95].

Gene expression patterns define the phenotypes of inflammatory breast cancer as well as those associated with tumor hypoxia, and gene signatures can predict residual malignancy in axillary lymph nodes after neoadjuvant chemotherapy [114].

In another study in the setting of neoadjuvant therapy, gene expression profiles did not predict response in locally advanced breast cancer [115]. A very recent study showed predictive signatures could be obtained from FNA biopsies, but these lost significance on multivariate analysis and did not correlate with in-vitro drug sensitivity-gene expression predictors based upon NCI-60 cell lines [116]. However, another recent study showed immune signalling molecules, such as DEFA and MAP2, a microtubule-associated protein, correlate with response to neoadjuvant taxane-based therapy [117].

In a retrospective study of 300 women, Osako et al. [118] found 30 (10\%) achieved pathological complete remission (pCR) and 22 (7\%) showed progressive disease (PD) after neoadjuvant chemotherapy (anthracycline-based, taxane, or both). Multivariate analysis demonstrated that anthracycline plus taxane chemotherapy, nuclear grade 3, estrogen (ER) or progesterone receptor (PR) negativity (note that they used a 10\% cut off point for positivity), and HER2-positivity were significant predictors of pCR, whereas clinical stage T3-4 and nuclear grade 3 were significant predictors of PD. They concluded that high-grade breast cancers include subsets both highly sensitive and highly resistant to cytotoxic neoadjuvant chemotherapy. ER/PR-negativity and HER2-positivity are predictive of chemosensitivity. Advanced primary tumor stage and high nuclear grade, but not ER or PR status, are predictive of chemoresistance [118].

\subsection{Protein Expression and Subcellular Location in Breast Cancer Cells}

Protein expression and subcellular location can reveal functional changes in specific proteins. $\mathrm{Fu}$ et al. used a dissociable antibody microarray (DAMA) to visualize subcellular locations of 325 proteins in seven breast cancer cell lines, and were able to demonstrate spatial distribution 
differences in cyclin B1 of the cancer cell lines in comparison to normal cells [119]. They also found that not all proteins occupy subcellular locations, as predicted by protein databases such as LOCATE (http://locate.imb.uq.edu.au/), a mammalian protein subcellular localization database, and the Human Protein Atlas (HPA) (http://www.proteinatlas.org/index.php). The antibodies for the arrays were obtained from Hypromatrix, Inc., which lists a repertoire of 400 antibodies that can be individually purchased, or bought as arrays for various high throughput protein screens, including phosphoprotein detection and signalling protein assessment (http://www.hypromatrix.com/).

Triple-negative breast cancers (TNBC), which are defined by a lack of expression of estrogen, progesterone, and HER2/neu receptors, comprise $15 \%$ of all breast cancers. However, they are considered to be a heterogeneous group [120-122]. This subtype has an aggressive behavior, poor prognosis, and is resistant to endocrine therapies [123].

Two groups have looked at protein profiles in TNBC using 2D DIGE (two-dimensional difference gel electrophoresis) and matrix-assisted laser desorption/ionization time-of-flight mass spectrometry (MALDI-TOFMS) [124] or reverse phase protein arrays for specific cyclin proteins, respectively [125]. 2D DIGE and MALDI-TOFMS revealed differential expression of glycolytic enzymes, such as MDH2, PGK1, TKT, Aldolase1, cytokeratins CK7, 8, 9, 14, 17, and 19, other structural proteins such as vimentin, fibronectin, and L-plastin, as well as lactoferrin, and members of the Annexin family [124]. Reverse phase protein arrays detected Cyclins B1, D1, and E1 with distinct expressions in different breast cancer subtypes. Cyclin E1 overexpression was unique to TNBC and basal-like cancers. CCNE1 copy number was increased in basal-like breast cancers when compared to that of other types of breast cancer, whereas $C C N B 1$ gene copy number change was not detected in breast cancer [125].

\subsection{Gene Copy Number and Response to Neoadjuvant Chemotherapy}

Post-neoadjuvant therapy gene copy number assessment in a small number of cases (45) has been claimed to have predictive value [126]. In this study, a 158 gene set was able to predict relapse, while a 51 gene set could predict outcome in poor responders, and a 32 gene set could predict outcome in good responders [126].

In a comprehensive study of seven breast cancer cell lines using the submegabase-resolution tiling (SMRT) array comparative genomic hybridization (aCGH) platform with a resolution of 80 kilobases, Shadeo and Lam have shown that 75 high-level gains and 48 losses were observed. Complex alterations with several levels of change were found on chromosome arms 1p, 8q, 9p, 11q, 15q, 17q, and 20q. Approximately 60 loci containing genes associated with the epidermal growth factor family (epidermal growth factor receptor, HER2, HER3, and HER4) showed copy number changes in multiple genes in these pathways in all seven cell lines [127]. These require validation in clinical samples and correlation with response to neoadjuvant therapies.

\subsection{Detection of Chromosomal Aneuploidies and Gene Copy Number Changes in Fine Needle Aspirates Is Diagnostic of Breast Cancer}

Certain probe panels alone have been reported to be able to distinguish breast cancer from benign lesions in cells obtained by fine needle aspirates in $100 \%$ of DNA aneuploid tumors and in $66 \%$ of DNA diploid tumors, independent of all of the other parameters evaluated [128]. 


\subsection{Translocations}

Colin Collins and others analyzed brain, breast, ovary, and prostate tumors, and breast cancer cell lines by using end sequencing profiling (ESP). They showed that these cells contain a large number of sequence-ready tumor genome breakpoints. Some rearrangements may be recurrent. Sequencing and fluorescence in situ hybridization confirmed the translocations, co-amplifications, and complexes of multiple genomic loci, with associated molecular heterogeneity [129]. By using multi-banding FISH (mFISH), Letessier et al. have demonstrated 136 break-regions in breast cancer cell lines [130].

\subsection{TP53 Mutations}

TP53 mutations have been correlated with p53 protein levels and chromosome 17 abnormalities (CEP 17 polysomies) in breast cancer. For instance, cells with p53 mutations showed abnormal p53 protein expression and a higher number of chromosome 17 copies than did cells without TP53 mutations [131]. This indicates that a combination of abnormal p53 expression and cep17 polysomy can be used as a surrogate marker for TP53 mutation. TP53 mutations are associated with worse outcomes [132-136]. Direct FISH based detection of point mutations in breast cancer cells is theoretically possible, as this has been done in microbes to predict antibiotic sensitivity [137].

\section{8. $m i R N A$}

Altered miRNA signatures in primary breast cancers and their metastasis have been observed, including the loss of tumor suppressor miRNAs (miR-206, miR-17-5p, miR-125a, miR-125b, miR-200, let-7, miR-34 and miR-31) and the overexpression of oncogenic miRNAs (miR-21, miR-155, miR-10b, miR-373 and miR-520c) [138]. VEGF expression in breast cancer cells is triggered by HIF-1 and STAT3 under the influence of miR-20b [139]. Tumor-specific miRNAs can be detected in peripheral blood samples from breast cancer patients, and blood levels of miR-195 and let$7 \mathrm{a}$ decreased to control levels after surgical excision of breast tumors. Specific circulating miRNAs correlate with nodal status and estrogen receptor status [140].

Although the detection of miRNAs in formalin fixed paraffin-embedded tissue by FISH is difficult because of their small size, Sempere et al. were able to detect miRNA expression in formalin-fixed paraffin sections of breast cancer tissue by using locked nucleic acid (LNA) FITC labelled DNA probes and tyramide signal amplification following binding with horseradish peroxidase conjugated to anti-FITC antibodies [141]. They found that the expression of miR-145 and miR-205 was localized to the myoepithelial/basal cell compartment of normal mammary ducts and lobules, with a reduction or complete loss of the two miRNAs in cancer cells. They also found, compared to normal cells, loss of let-7 (lethal-7) gene expression by FISH in cancer cells in both in-situ cancers (CIS) and invasive cancers. MiR-21 expression is increased in cancer cells and tumor-associated fibroblasts. This would suggest that the lack of mir-145, miR-205, let-7, and an increased expression of miR-21 could be used to distinguish between neoplastic and non-neoplastic epithelial cells in fine-needle aspiration biopsy samples. 


\subsection{Fusion Genes}

Fusion events are poorly characterized in clinical breast cancer tissue. Cell line data suggest that fusion events may be quite common. Examples include UBR4-GBL1, ARHGEF2-SULF2, AHCYL1-RAD51C, RAD51C-ATXN7, BCAS4-BCAS3 and IRA1-RGS17, as well as chimeric transcripts giving rise to fusion proteins (reviewed by Edwards, [142]).

\subsection{Cancer Stem Cells in NSCLC and Breast Cancer}

Cancer stem cells (CSC) have become an area of interest in a number of tumor types and are thought to be chemoresistant cells $[143,144]$. A commonly used marker of stem cells is CD133 (prominin-1) [145]. Using immunohistochemistry in primary lung cancers, an average percentage of epithelial cells expressing CD133 was found to be 5\%, with a range of 0.02 to $35 \%$ CD133+ cells in lung cancer, as detected by flow cytometry [146]. Such cells are cisplatin resistant both in vitro and in vivo. Patients with $\mathrm{CD} 133+$ cells in their lung tumors tended to have a shorter progression-free survival [146]. Chemotherapeutic agents used commonly in NSCLC therapy result in enrichment of CSC [147], which are highly tumorigenic and metastatic [148]. Although CD133 is a marker of chemoresistance, it does not function as a prognostic marker for survival in NSCLC patients [149].

Breast CSCs have been identified by using a model in which human breast cancer cells were grown in immunocompromised mice. Only a minority of breast cancer cells with the phenotype CD44+ CD24-/low, starting with as few as 100 cells, were able to form tumors in NOD/SCID mice, whereas thousands of cells without this phenotype could not give rise to tumors in NOD/SCID mice [150]. High grade breast cancers have a higher content of CSCs than do low grade cancers [151].

\subsection{Plasticity of Cancer Stem Cells}

As each nucleated cell contains the entire genome of each individual, the maintenance of cellular normality, homeostasis, repair, and the maintenance or regeneration of organ structure, must be a complex and active process, and not an irreversible "turning off or on" of specific subsets of genes and their encoded proteins. In human cancers, the evidence for this includes metaplastic cancers [152], the inappropriate co-expression of lineage specific markers [153], and the maturation of cell types in certain paediatric sarcomas over time [154]. Cancer stem cells are thought to be pluripotent and thus could, over time, lead to outgrowth of cells with phenotypes that do not resemble the original clone. This fundamentally creates flaws in any type of classification system that is based on tissue of origin, cell type, phenotype, grade, etc., as these assume that a pre-treatment snap-shot based upon static classification systems is capable of providing prognostic or predictive information about an individual patient with cancer. Complicating this is the fact that gene expression is controlled by the interaction of cells with their microenvironment, and vice versa [155-161]. Thus, instead of classifying cancers on the basis of organ of origin, cell type, differentiation, phenotype, etc., we need to develop a functional, dynamic, pathway-based classification system that is agnostic of organ type or cellular origin, but more predictive of the probability of response to targeted therapies. Such classification systems would allow the selection of appropriate targeted therapies that are individualized and modified, as the tumor clones continue to evolve during therapy. 


\subsection{Next Generation Sequencing Technology and Cancer Genomes}

The functional classification of human cancers using current techniques is too cumbersome and expensive. The methods are numerous, each with a limited set of data available for developing a comprehensive map of pathway pathology in each individual cancer sample. Next generation sequencing, however, promises to significantly change this [162-177]. In the next few years, the cost and turnaround time of whole genome sequencing is expected to be competitive with conventional assays that provide only limited clinically useful information [166]. The technology has already allowed great insight into cancer cells and has enabled the recognition of novel markers of diagnostic importance [167-180]. If future comprehensive pathway analysis costs come down to around $\$ 1000$ per patient as expected using the next generation sequencing technologies, the avoidable costs of ineffective therapies could reach up to CAN\$1.1 billion per year for Canadian cancer patients (Table 3). Thus over a billion dollars (Canadian funds) could be redirected annually towards newer targeted therapies, which should yield better outcomes than the current "one size fits all" approach.

Table 3. Future ROI after test optimization example, in Canadian dollars.

\begin{tabular}{lllll}
\hline & $\begin{array}{c}\text { Patients to be } \\
\text { tested per year }\end{array}$ & $\begin{array}{c}\text { Test cost per } \\
\text { year }\end{array}$ & $\begin{array}{c}\text { ROI per year } \\
\text { (Cost avoidance) }\end{array}$ & Net savings \\
\hline Top 5 cancers & 59,000 & $\$ 59,000,000$ & $\$ 989,470,619$ & $\$ 930,470,619$ \\
Top 10 cancers & 107,350 & $\$ 107,350,000$ & $\$ 1,178,328,829$ & $\$ 1,070,978,829$ \\
Top 14 cancers & 120,150 & $\$ 120,150,000$ & $\$ 1,208,911,725$ & $\$ 1,088,761,725$ \\
\hline
\end{tabular}

Optimized assay cost per test (labor and materials), $\$ 1,000$;

$\mathrm{ROI}=$ Return on investment.

\section{Conclusions}

Intratumoral and intertumoral heterogeneity, tumor microenvironments, and individual genomes are likely to account for the variability of response to current therapies, conventional or targeted. Morphologic classification systems based upon the light microscopic features of human cancers are unlikely to be refined further, even with ancillary methods, such as immunohistochemistry and in situ hybridization, as the information gleaned from such methods will remain relatively limited in scope and prone to interobserver variability. In order to develop functional classification systems, we have to wean ourselves from static morphology based classification systems and adopt systems based upon pathway pathology maps generated by robust, massively parallel next generation sequencing technologies. Once such technologies become cost-effective and timely, they may consistently generate clinically reliable data that will allow personalized therapies. Due to the massive data sets that would be generated, advances in bioinformatics and computing power will be required. Bioinformaticians will need to be incorporated into the staffing plans for clinical laboratories for this to become the future of cancer diagnostics.

\section{References}

1. Uluc, K.; Kujoth, G.C.; Baskaya, M.K. Operating microscopes: past, present, and future. Neurosurg. Focus 2009, 27, E4. 
2. Titford, M. The long history of hematoxylin. Biotech. Histochem. 2005, 80, 73-78.

3. Miyamoto, H.; Miller, J.S.; Fajardo, D.A.; Lee, T.K.; Netto, G.J.; Epstein, J.I. Non-invasive papillary urothelial neoplasms: the $2004 \mathrm{WHO} / \mathrm{ISUP}$ classification system. Pathol. Int. 2010, 60, $1-8$.

4. Hodges, K.B.; Lopez-Beltran, A.; Davidson, D.D.; Montironi, R.; Cheng, L. Urothelial dysplasia and other flat lesions of the urinary bladder: clinicopathologic and molecular featuRes. Hum. Pathol. 2010, 41, 155-162.

5. D'Angelo, E.; Prat, J. Uterine sarcomas: a review. Gynecol. Oncol. 2010, 116, 131-139.

6. Weis, E.; Rootman, J.; Joly, T.J.; Berean, K.W.; Al-Katan, H.M.; Pasternak, S.; Bonavolonta, G.; Strianese, D.; Saeed, P.; Feldman, K.A.; Vangveeravong, S.; Lapointe, J.S.; White, V.A. Epithelial lacrimal gland tumors: pathologic classification and current understanding. Arch. Ophthalmol. 2009, 127, 1016-1028.

7. Wallace, W.A. The challenge of classifying poorly differentiated tumors in the lung. Histopathology 2009, 54, 28-42.

8. Tefferi, A.; Thiele, J.; Vardiman, J.W. The 2008 World Health Organization classification system for myeloproliferative neoplasms: order out of chaos. Cancer 2009, 115, 3842-3847.

9. Scheithauer, B.W. Development of the WHO classification of tumors of the central nervous system: a historical perspective. Brain Pathol. 2009, 19, 551-564.

10. Grignon, D.J. The current classification of urothelial neoplasms. Mod. Pathol. 2009, 22 (Suppl. 2), S60-S69.

11. Verghese, E.T.; den Bakker, M.A.; Campbell, A.; Hussein, A.; Nicholson, A.G.; Rice, A.; Corrin, B.; Rassl, D.; Langman, G.; Monaghan, H.; Gosney, J.; Seet, J.; Kerr, K.; Suvarna, S.K.; Burke, M.; Bishop, P.; Pomplun, S.; Willemsen, S.; Addis, B. Interobserver variation in the classification of thymic tumors - a multicenter study using the WHO classification system. Histopathology 2008, 53, 218-223.

12. Trembath, D.; Miller, C.R.; Perry, A. Gray zones in brain tumor classification: evolving concepts. Adv. Anat. Pathol. 2008, 15, 287-297.

13. Schiffer, C.A. World Health Organization and international prognostic scoring system: the limitations of current classification systems in assessing prognosis and determining appropriate therapy in myelodysplastic syndromes. Semin. Hematol. 2008, 45, 3-7.

14. Scheithauer, B.W.; Fuller, G.N.; VandenBerg, S.R. The 2007 WHO classification of tumors of the nervous system: controversies in surgical neuropathology. Brain Pathol. 2008, 18, 307-316.

15. Okumura, M.; Shiono, H.; Minami, M.; Inoue, M.; Utsumi, T.; Kadota, Y.; Sawa, Y. Clinical and pathological aspects of thymic epithelial tumors. Gen. Thorac. Cardiovasc. Surg. 2008, 56, $10-16$.

16. Marchevsky, A.M.; McKenna, R.J., Jr.; Gupta, R. Thymic epithelial neoplasms: a review of current concepts using an evidence-based pathology approach. Hematol. Oncol. Clin. North Am. 2008, 22, 543-562.

17. Ito, Y.; Hirokawa, M.; Fukushima, M.; Inoue, H.; Yabuta, T.; Uruno, T.; Kihara, M.; Higashiyama, T.; Takamura, Y.; Miya, A.; Kobayashi, K.; Matsuzuka, F.; Miyauchi, A. Prevalence and prognostic significance of poor differentiation and tall cell variant in papillary carcinoma in Japan. World J. Surg. 2008, 32, 1535-1543. 
18. Fuller, G.N. The WHO Classification of Tumors of the Central Nervous System, 4th edition. Arch. Pathol. Lab. Med. 2008, 132, 906.

19. Egevad, L. Recent trends in Gleason grading of prostate cancer: I. Pattern interpretation. Anal. Quant. Cytol. Histol. 2008, 30, 190-198.

20. Burger, M.; Denzinger, S.; Wieland, W.F.; Stief, C.G.; Hartmann, A.; Zaak, D. Does the current World Health Organization classification predict the outcome better in patients with noninvasive bladder cancer of early or regular onset? BJU Int. 2008, 102, 194-197.

21. Ferrone, C.R.; Tang, L.H.; Tomlinson, J.; Gonen, M.; Hochwald, S.N.; Brennan, M.F.; Klimstra, D.S.; Allen, P.J. Determining prognosis in patients with pancreatic endocrine neoplasms: can the WHO classification system be simplified? J. Clin. Oncol. 2007, 25, 5609-5615.

22. Riquet, M.; Foucault, C.; Berna, P.; Assouad, J.; Dujon, A.; Danel, C. Prognostic value of histology in resected lung cancer with emphasis on the relevance of the adenocarcinoma subtyping. Ann. Thorac. Surg. 2006, 81, 1988-1995.

23. Pajtler, M.; Audy-Jurkovic, S.; Milicic-Juhas, V.; Staklenac, B.; Pauzar, B. Interobserver variability in cytologic subclassification of squamous intraepithelial lesions--the Bethesda System vs. World Health Organization classification. Coll. Antropol. 2006, 30, 137-142.

24. Epstein, J.I.; Allsbrook, W.C., Jr.; Amin, M.B.; Egevad, L.L. Update on the Gleason grading system for prostate cancer: results of an international consensus conference of urologic pathologists. Adv. Anat. Pathol. 2006, 13, 57-59.

25. Willis, J.; Smith, C.; Ironside, J.W.; Erridge, S.; Whittle, I.R.; Everington, D. The accuracy of meningioma grading: a 10-year retrospective audit. Neuropathol. Appl. Neurobiol. 2005, 31, 141-149.

26. Oyama, T.; Allsbrook, W.C., Jr.; Kurokawa, K.; Matsuda, H.; Segawa, A.; Sano, T.; Suzuki, K.; Epstein, J.I. A comparison of interobserver reproducibility of Gleason grading of prostatic carcinoma in Japan and the United States. Arch. Pathol. Lab. Med. 2005, 129, 1004-1010.

27. Wolfson, W.L. Interobserver variability among expert uropathologists. Am. J. Surg.Pathol. 2009, 33, 801-802.

28. Izadi-Mood, N.; Yarmohammadi, M.; Ahmadi, S.A.; Irvanloo, G.; Haeri, H.; Meysamie, A.P.; Khaniki, M. Reproducibility determination of WHO classification of endometrial hyperplasia/well differentiated adenocarcinoma and comparison with computerized morphometric data in curettage specimens in Iran. Diagn. Pathol. 2009, 4, 10.

29. Eefting, D.; Schrage, Y.M.; Geirnaerdt, M.J.; Le Cessie, S.; Taminiau, A.H.; Bovee, J.V.; Hogendoorn, P.C. Assessment of interobserver variability and histologic parameters to improve reliability in classification and grading of central cartilaginous tumors. Am. J. Surg. Pathol. 2009, $33,50-57$.

30. Darvishian, F.; Singh, B.; Simsir, A.; Ye, W.; Cangiarella, J.F. Atypia on breast core needle biopsies: reproducibility and significance. Ann. Clin. Lab. Sci. 2009, 39, 270-276.

31. Adams, A.L.; Chhieng, D.C.; Bell, W.C.; Winokur, T.; Hameed, O. Histologic grading of invasive lobular carcinoma: does use of a 2-tiered nuclear grading system improve interobserver variability? Ann. Diagn. Pathol. 2009, 13, 223-225.

32. Mhawech-Fauceglia, P.; Herrmann, F.; Bshara, W.; Zhang, S.; Penetrante, R.; Lele, S.; Odunsi, K.; Rodabaugh, K. Intraobserver and interobserver variability in distinguishing between 
endocervical and endometrial adenocarcinoma on problematic cases of cervical curettings. Int. J. Gynecol. Pathol. 2008, 27, 431-436.

33. Kummerlin, I.; ten Kate, F.; Smedts, F.; Horn, T.; Algaba, F.; Trias, I.; de la Rosette, J.; Laguna, M.P. Core biopsies of renal tumors: a study on diagnostic accuracy, interobserver, and intraobserver variability. Eur. Urol. 2008, 53, 1219-1225.

34. Gilles, F.H.; Tavare, C.J.; Becker, L.E.; Burger, P.C.; Yates, A.J.; Pollack, I.F.; Finlay, J.L. Pathologist interobserver variability of histologic featuRes. in childhood brain tumors: Results from the CCG-945 study. Pediatr. Dev. Pathol. 2008, 11, 108-117.

35. Evans, A.J.; Henry, P.C.; Van der Kwast, T.H.; Tkachuk, D.C.; Watson, K.; Lockwood, G.A.; Fleshner, N.E.; Cheung, C.; Belanger, E.C.; Amin, M.B.; Boccon-Gibod, L.; Bostwick, D.G.; Egevad, L.; Epstein, J.I.; Grignon, D.J.; Jones, E.C.; Montironi, R.; Moussa, M.; Sweet, J.M.; Trpkov, K.; Wheeler, T.M.; Srigley, J.R. Interobserver variability between expert urologic pathologists for extraprostatic extension and surgical margin status in radical prostatectomy specimens. Am. J. Surg. Pathol. 2008, 32, 1503-1512.

36. Elsheikh, T.M.; Asa, S.L.; Chan, J.K.; DeLellis, R.A.; Heffess, C.S.; LiVolsi, V.A.; Wenig, B.M. Interobserver and intraobserver variation among experts in the diagnosis of thyroid follicular lesions with borderline nuclear featuRes. of papillary carcinoma. Am. J. Clin. Pathol. 2008, 130, 736-744.

37. Veloso, S.G.; Lima, M.F.; Salles, P.G.; Berenstein, C.K.; Scalon, J.D.; Bambirra, E.A. Interobserver agreement of Gleason score and modified Gleason score in needle biopsy and in surgical specimen of prostate cancer. Int. Braz. J. Urol. 2007, 33, 639-646; discussion 647-651.

38. Gonul, I.I.; Poyraz, A.; Unsal, C.; Acar, C.; Alkibay, T. Comparison of 1998 WHO/ISUP and 1973 WHO classifications for interobserver variability in grading of papillary urothelial neoplasms of the bladder. Pathological evaluation of 258 cases. Urol. Int. 2007, 78, 338-344.

39. Engers, R. Reproducibility and reliability of tumor grading in urological neoplasms. World J. Urol. 2007, 25, 595-605.

40. Vainer, B. Interobserver variability in gastrointestinal pathology. Scand. J. Gastroenterol. 2006, 41, 765-766.

41. Raab, S.S.; Meier, F.A.; Zarbo, R.J.; Jensen, D.C.; Geisinger, K.R.; Booth, C.N.; Krishnamurti, U.; Stone, C.H.; Janosky, J.E.; Grzybicki, D.M. The "Big Dog" effect: variability assessing the causes of error in diagnoses of patients with lung cancer. J. Clin. Oncol. 2006, 24, 2808-2814.

42. Glaessgen, A.; Hamberg, H.; Pihl, C.G.; Sundelin, B.; Nilsson, B.; Egevad, L. Interobserver reproducibility of percent Gleason grade $4 / 5$ in prostate biopsies. J. Urol. 2004, 171, 664-667.

43. Costantini, M.; Sciallero, S.; Giannini, A.; Gatteschi, B.; Rinaldi, P.; Lanzanova, G.; Bonelli, L.; Casetti, T.; Bertinelli, E.; Giuliani, O.; Castiglione, G.; Mantellini, P.; Naldoni, C.; Bruzzi, P. Interobserver agreement in the histologic diagnosis of colorectal polyps. the experience of the multicenter adenoma colorectal study (SMAC). J. Clin. Epidemiol. 2003, 56, 209-214.

44. Nicholson, A.G.; Perry, L.J.; Cury, P.M.; Jackson, P.; McCormick, C.M.; Corrin, B.; Wells, A.U. Reproducibility of the WHO/IASLC grading system for pre-invasive squamous lesions of the bronchus: a study of inter-observer and intra-observer variation. Histopathology 2001, 38, 202-208. 
45. Granados, R.; Aramburu, J.A.; Murillo, N.; Camarmo, E.; de la Cal, M.A.; Fernandez-Segoviano, P. Fine-needle aspiration biopsy of liver masses: diagnostic value and reproducibility of cytological criteria. Diagn. Cytopathol. 2001, 25, 365-375.

46. Jaffe, E.S.; Harris, N.L.; Stein, H.; Isaacson, P.G. Classification of lymphoid neoplasms: the microscope as a tool for disease discovery. Blood 2008, 112, 4384-4399.

47. He, Y.D.; Friend, S.H. Microarrays--the 21 st century divining rod? Nat. Med. 2001, 7, 658-659.

48. Fujita, H.; So, Y.; Asada, Y.; Tatibana, K.; Hayakawa, M.; Matuo, T.; Minami, T.; Imamura, S.; Fujisawa, S.; Ito, K. Studies on lymphoma, reticulosis and its related diseases, especially about classification, histology and cytology with electron microscopy. Hifuka Kiyo 1962, 57, 3-61.

49. Kohler, G.; Milstein, C. Continuous cultuRes. of fused cells secreting antibody of predefined specificity. Nature 1975, 256, 495-497.

50. Mullis, K.; Faloona, F.; Scharf, S.; Saiki, R.; Horn, G.; Erlich, H. Specific enzymatic amplification of DNA in vitro: the polymerase chain reaction. Cold Spring Harb. Symp. Quant. Biol. 1986, 51, 263-273.

51. Herzenberg, L.A.; Parks, D.; Sahaf, B.; Perez, O.; Roederer, M. The history and future of the fluorescence activated cell sorter and flow cytometry: a view from Stanford. Clin. Chem. 2002, 48, 1819-1827.

52. Pennisi, E. Human genome: Finally, the book of life and instructions for navigating it. Science 2000, 288, 2304-2307.

53. Canadian Institute for Health Information. Drug Expenditure in Canada, 1985 to 2008; Canadian Institute for Health Information: Ottawa, Ontario, Canada, 2009.

54. Spear, B.B.; Heath-Chiozzi, M.; Huff, J. Clinical application of pharmacogenetics. Trends Mol. Med. 2001, 7, 201-204.

55. Parkin, D.M.; Bray, F.; Ferlay, J.; Pisani, P. Global Cancer Statistics, 2002. CA Cancer J. Clin. 2005, 55, 74-108.

56. World Health Organization. Cancer. Fact sheet No. 297; WHO: Geneva, Swizerland, 2009.

57. US National Cancer Insitute. Surveillance, Epidemiology and End Results (SEER) Program; NCI: Rockville, MD, USA, 2009; Available online: http://seer.cancer.gov/ (accessed online on 24 May 2010).

58. Rossi, G.; Pelosi, G.; Graziano, P.; Barbareschi, M.; Papotti, M. A reevaluation of the clinical significance of histological subtyping of non--small-cell lung carcinoma: diagnostic algorithms in the era of personalized treatments. Int. J. Surg. Pathol. 2009, 17, 206-218.

59. Travis, W.D.; Brambilla, E.; Muller-Hermelink, H.K.; Harris, C.C. Pathology and Genetics of Tumors of the Lung, Pleura,Thymus and Heart; 4th ed.; IARC Press: Lyon, France, 2004.

60. Thomas, J.S.; Lamb, D.; Ashcroft, T.; Corrin, B.; Edwards, C.W.; Gibbs, A.R.; Kenyon, W.E.; Stephens, R.J.; Whimster, W.F. How reliable is the diagnosis of lung cancer using small biopsy specimens? Report of a UKCCCR Lung Cancer Working Party. Thorax 1993, 48, 1135-1139.

61. Edwards, S.L.; Roberts, C.; McKean, M.E.; Cockburn, J.S.; Jeffrey, R.R.; Kerr, K.M. Preoperative histological classification of primary lung cancer: accuracy of diagnosis and use of the non-small cell category. J. Clin. Pathol. 2000, 53, 537-540.

62. Trani, L.; Myerson, J.; Ashley, S.; Young, K.; Sheri, A.; Hubner, R.; Puglisi, M.; Popat, S.; O'Brien, M.E. Histology classification is not a predictor of clinical outcomes in advanced non- 
small cell lung cancer (NSCLC) treated with vinorelbine or gemcitabine combinations. Lung Cancer 2010, doi:10.1016/j.lungcan.2010.02.003.

63. Hirsch, F.R.; Spreafico, A.; Novello, S.; Wood, M.D.; Simms, L.; Papotti, M. The prognostic and predictive role of histology in advanced non-small cell lung cancer: a literature review. J. Thorac. Oncol. 2008, 3, 1468-1481.

64. Pelosi, G.; Fraggetta, F.; Pasini, F.; Maisonneuve, P.; Sonzogni, A.; Iannucci, A.; Terzi, A.; Bresaola, E.; Valduga, F.; Lupo, C.; Viale, G. Immunoreactivity for thyroid transcription factor-1 in stage I non-small cell carcinomas of the lung. Am. J. Surg. Pathol. 2001, 25, 363-372.

65. Tan, D.; Li, Q.; Deeb, G.; Ramnath, N.; Slocum, H.K.; Brooks, J.; Cheney, R.; Wiseman, S.; Anderson, T.; Loewen, G. Thyroid transcription factor-1 expression prevalence and its clinical implications in non-small cell lung cancer: a high-throughput tissue microarray and immunohistochemistry study. Hum. Pathol. 2003, 34, 597-604.

66. Au, N.H.C.M.; Gown, A.M.M.; Cheang, M.M.; Huntsman, D.M.; Yorida, E.B.; Elliott, W.M.P.; Flint, J.M.; English, J.M.; Gilks, C.B.M.; Grimes, H.L.P. p63 Expression in Lung Carcinoma: A Tissue Microarray Study of 408 Cases. Appl. Immunohistochem. Mol. Morphol. 2004, 12, 240-247.

67. Monica, V.; Ceppi, P.; Righi, L.; Tavaglione, V.; Volante, M.; Pelosi, G.; Scagliotti, G.V.; Papotti, M. Desmocollin-3: a new marker of squamous differentiation in undifferentiated largecell carcinoma of the lung. Mod. Pathol. 2009, 22, 709-717.

68. Wigle, D.A.; Jurisica, I.; Radulovich, N.; Pintilie, M.; Rossant, J.; Liu, N.; Lu, C.; Woodgett, J.; Seiden, I.; Johnston, M.; Keshavjee, S.; Darling, G.; Winton, T.; Breitkreutz, B.J.; Jorgenson, P.; Tyers, M.; Shepherd, F.A.; Tsao, M.S. Molecular profiling of non-small cell lung cancer and correlation with disease-free survival. Cancer Res. 2002, 62, 3005-3008.

69. Blackhall, F.H.; Wigle, D.A.; Jurisica, I.; Pintilie, M.; Liu, N.; Darling, G.; Johnston, M.R.; Keshavjee, S.; Waddell, T.; Winton, T.; Shepherd, F.A.; Tsao, M.S. Validating the prognostic value of marker genes derived from a non-small cell lung cancer microarray study. Lung Cancer 2004, 46, 197-204.

70. Choi, N.; Son, D.S.; Lee, J.; Song, I.S.; Kim, K.A.; Park, S.H.; Lim, Y.S.; Seo, G.J.; Han, J.; Kim, H.; Lee, H.W.; Kang, J.J.; Seo, J.S.; Kim, J.H.; Kim, J. The signature from messenger RNA expression profiling can predict lymph node metastasis with high accuracy for non-small cell lung cancer. J. Thorac. Oncol. 2006, 1, 622-628.

71. Potti, A.; Mukherjee, S.; Petersen, R.; Dressman, H.K.; Bild, A.; Koontz, J.; Kratzke, R.; Watson, M.A.; Kelley, M.; Ginsburg, G.S.; West, M.; Harpole, D.H. Jr.; Nevins, J.R. A genomic strategy to refine prognosis in early-stage non-small-cell lung cancer. N. Engl. J. Med. 2006, 355, 570-580.

72. Corson, T.W.; Zhu, C.Q.; Lau, S.K.; Shepherd, F.A.; Tsao, M.S.; Gallie, B.L. KIF14 messenger RNA expression is independently prognostic for outcome in lung cancer. Clin. Cancer Res. 2007, $13,3229-3234$.

73. Guo, N.L.; Wan, Y.W.; Tosun, K.; Lin, H.; Msiska, Z.; Flynn, D.C.; Remick, S.C.; Vallyathan, V.; Dowlati, A.; Shi, X.; Castranova, V.; Beer, D.G.; Qian, Y. Confirmation of gene expressionbased prediction of survival in non-small cell lung cancer. Clin. Cancer Res. 2008, 14, 8213-8220. 
74. Lonergan, K.M.; Chari, R.; Coe, B.P.; Wilson, I.M.; Tsao, M.S.; Ng, R.T.; Macaulay, C.; Lam, S.; Lam, W.L. Transcriptome profiles of carcinoma-in-situ and invasive non-small cell lung cancer as revealed by SAGE. PLoS One 2010, 5, e9162.

75. Zhu, C.Q.; Blackhall, F.H.; Pintilie, M.; Iyengar, P.; Liu, N.; Ho, J.; Chomiak, T.; Lau, D.; Winton, T.; Shepherd, F.A.; Tsao, M.S. Skp2 gene copy number aberrations are common in nonsmall cell lung carcinoma, and its overexpression in tumors with ras mutation is a poor prognostic marker. Clin. Cancer Res. 2004, 10, 1984-1991.

76. Zhu, C.Q.; Cutz, J.C.; Liu, N.; Lau, D.; Shepherd, F.A.; Squire, J.A.; Tsao, M.S. Amplification of telomerase (hTERT) gene is a poor prognostic marker in non-small-cell lung cancer. $B r . J$. Cancer 2006, 94, 1452-1459.

77. Go, H.; Jeon, Y.K.; Park, H.J.; Sung, S.W.; Seo, J.W.; Chung, D.H. High MET gene copy number leads to shorter survival in patients with non-small cell lung cancer. J. Thorac. Oncol. 2010, 5, 305-313.

78. Tsao, M.S.; Sakurada, A.; Cutz, J.C.; Zhu, C.Q.; Kamel-Reid, S.; Squire, J.; Lorimer, I.; Zhang, T.; Liu, N.; Daneshmand, M.; Marrano, P.; da Cunha Santos, G.; Lagarde, A.; Richardson, F.; Seymour, L.; Whitehead, M.; Ding, K.; Pater, J.; Shepherd, F.A. Erlotinib in lung cancer molecular and clinical predictors of outcome. N. Engl. J. Med. 2005, 353, 133-144.

79. Zhu, C.; da Cunha Santos, G.; Ding, K.; Sakurada, A.; Cutz, J.; Liu, N.; Zhang, T.; Marrano, P.; Whitehead, M.; Squire, J.; Kamel-Reid, S.; Seymour, L.; Shepherd, F.; Tsao, M. Role of KRAS and EGFR as biomarkers of response to erlotinib in National Cancer Institute of Canada Clinical Trials Group Study BR.21. J. Clin. Oncol. 2008, 26, 4268-4275.

80. Dahabreh, I.; Linardou, H.; Siannis, F.; Kosmidis, P.; Bafaloukos, D.; Murray, S. Somatic EGFR mutation and gene copy gain as predictive biomarkers for response to tyrosine kinase inhibitors in non-small cell lung cancer. Clin. Cancer Res. 2010, 16, 291-303.

81. Lynch, T.; Bell, D.; Sordella, R.; Gurubhagavatula, S.; Okimoto, R.; Brannigan, B.; Harris, P.; Haserlat, S.; Supko, J.; Haluska, F.; Louis, D.; Christiani, D.; Settleman, J.; Haber, D. Activating mutations in the epidermal growth factor receptor underlying responsiveness of non-small-cell lung cancer to gefitinib. N. Engl. J. Med. 2004, 350, 2129-2139.

82. Paez, J.; Jänne, P.; Lee, J.; Tracy, S.; Greulich, H.; Gabriel, S.; Herman, P.; Kaye, F.; Lindeman, N.; Boggon, T.; Naoki, K.; Sasaki, H.; Fujii, Y.; Eck, M.; Sellers, W.; Johnson, B.; Meyerson, M. EGFR mutations in lung cancer: correlation with clinical response to gefitinib therapy. Science 2004, 304, 1497-1500.

83. Price, D.; Figg, W. Mutations in the EGFR: the importance of genotyping. Cancer Biol. Ther. 2004, 3, 434-435.

84. Bell, D.; Lynch, T.; Haserlat, S.; Harris, P.; Okimoto, R.; Brannigan, B.; Sgroi, D.; Muir, B.; Riemenschneider, M.; Iacona, R.; Krebs, A.; Johnson, D.; Giaccone, G.; Herbst, R.; Manegold, C.; Fukuoka, M.; Kris, M.; Baselga, J.; Ochs, J.; Haber, D. Epidermal growth factor receptor mutations and gene amplification in non-small-cell lung cancer: molecular analysis of the IDEAL/INTACT gefitinib trials. J. Clin. Oncol. 2005, 23, 8081-8092.

85. Kelly, K.; Chansky, K.; Gaspar, L.; Albain, K.; Jett, J.; Ung, Y.; Lau, D.; Crowley, J.; Gandara, D. Phase III trial of maintenance gefitinib or placebo after concurrent chemoradiotherapy and 
docetaxel consolidation in inoperable stage III non-small-cell lung cancer: SWOG S0023. J. Clin. Oncol. 2008, 26, 2450-2456.

86. Valencia-Sanchez, M.A.; Liu, J.; Hannon, G.J.; Parker, R. Control of translation and mRNA degradation by miRNAs and siRNAs. Genes Dev. 2006, 20, 515-524.

87. Bishop, J.A.; Benjamin, H.; Cholakh, H.; Chajut, A.; Clark, D.P.; Westra, W.H. Accurate classification of non-small cell lung carcinoma using a novel microRNA-based approach. Clin. Cancer Res. 2010, 16, 610-619.

88. Hu, Z.; Chen, X.; Zhao, Y.; Tian, T.; Jin, G.; Shu, Y.; Chen, Y.; Xu, L.; Zen, K.; Zhang, C.; Shen, H. Serum MicroRNA signatures identified in a genome-wide serum microrna expression profiling predict survival of non-small-cell lung cancer. J. Clin. Oncol. 2010, 28, 1721-1726.

89. Yu, L.; Todd, N.W.; Xing, L.; Xie, Y.; Zhang, H.; Liu, Z.; Fang, H.; Zhang, J.; Katz, R.L.; Jiang, F. Early detection of lung adenocarcinoma in sputum by a panel of microRNA markers. Int. J. Cancer 2010, doi:10.1002/ijc.25289.

90. Perou, C.M.; Sorlie, T.; Eisen, M.B.; van de Rijn, M.; Jeffrey, S.S.; Rees, C.A.; Pollack, J.R.; Ross, D.T.; Johnsen, H.; Akslen, L.A.; Fluge, O.; Pergamenschikov, A.; Williams, C.; Zhu, S.X.; Lonning, P.E.; Borresen-Dale, A.L.; Brown, P.O.; Botstein, D. Molecular portraits of human breast tumors. Nature 2000, 406, 747-752.

91. Lonning, P.E.; Sorlie, T.; Perou, C.M.; Brown, P.O.; Botstein, D.; Borresen-Dale, A.L. Microarrays in primary breast cancer--lessons from chemotherapy studies. Endocr. Relat. Cancer 2001, 8, 259-263.

92. Sorlie, T.; Perou, C.M.; Tibshirani, R.; Aas, T.; Geisler, S.; Johnsen, H.; Hastie, T.; Eisen, M.B.; van de Rijn, M.; Jeffrey, S.S.; Thorsen, T.; Quist, H.; Matese, J.C.; Brown, P.O.; Botstein, D.; Eystein Lonning, P.; Borresen-Dale, A.L. Gene expression patterns of breast carcinomas distinguish tumor subclasses with clinical implications. Proc. Natl. Acad. Sci. USA 2001, 98, 10869-10874.

93. Sorlie, T.; Tibshirani, R.; Parker, J.; Hastie, T.; Marron, J.S.; Nobel, A.; Deng, S.; Johnsen, H.; Pesich, R.; Geisler, S.; Demeter, J.; Perou, C.M.; Lonning, P.E.; Brown, P.O.; Borresen-Dale, A.L.; Botstein, D. Repeated observation of breast tumor subtypes in independent gene expression data sets. Proc. Natl. Acad. Sci. USA 2003, 100, 8418-8423.

94. Rouzier, R.; Perou, C.M.; Symmans, W.F.; Ibrahim, N.; Cristofanilli, M.; Anderson, K.; Hess, K.R.; Stec, J.; Ayers, M.; Wagner, P.; Morandi, P.; Fan, C.; Rabiul, I.; Ross, J.S.; Hortobagyi, G.N.; Pusztai, L. Breast cancer molecular subtypes respond differently to preoperative chemotherapy. Clin. Cancer Res. 2005, 11, 5678-5685.

95. Sotiriou, C.; Powles, T.J.; Dowsett, M.; Jazaeri, A.A.; Feldman, A.L.; Assersohn, L.; Gadisetti, C.; Libutti, S.K.; Liu, E.T. Gene expression profiles derived from fine needle aspiration correlate with response to systemic chemotherapy in breast cancer. Breast Cancer Res. 2002, 4, R3.

96. van de Vijver, M.; He, Y.; van't Veer, L.; Dai, H.; Hart, A.; Voskuil, D.; Schreiber, G.; Peterse, J.; Roberts, C.; Marton, M.; Parrish, M.; Atsma, D.; Witteveen, A.; Glas, A.; Delahaye, L.; van der Velde, T.; Bartelink, H.; Rodenhuis, S.; Rutgers, E.; Friend, S.; Bernards, R. A geneexpression signature as a predictor of survival in breast cancer. N. Engl. J. Med. 2002, 347, 1999-2009. 
97. Ma, X.J.; Salunga, R.; Tuggle, J.T.; Gaudet, J.; Enright, E.; McQuary, P.; Payette, T.; Pistone, M.; Stecker, K.; Zhang, B.M.; Zhou, Y.X.; Varnholt, H.; Smith, B.; Gadd, M.; Chatfield, E.; Kessler, J.; Baer, T.M.; Erlander, M.G.; Sgroi, D.C. Gene expression profiles of human breast cancer progression. Proc. Natl. Acad. Sci. USA 2003, 100, 5974-5979.

98. Weigelt, B.; Glas, A.; Wessels, L.; Witteveen, A.; Peterse, J.; van't Veer, L. Gene expression profiles of primary breast tumors maintained in distant metastases. Proc. Natl. Acad. Sci. USA 2003, 100, 15901-15905.

99. Fischer, D.C.; Noack, K.; Runnebaum, I.B.; Watermann, D.O.; Kieback, D.G.; Stamm, S.; Stickeler, E. Expression of splicing factors in human ovarian cancer. Oncol. Rep. 2004, 11, 1085-1090.

100. Weigelt, B.; van't Veer, L. Hard-wired genotype in metastatic breast cancer. Cell Cycle 2004, 3, 756-757.

101. Nakatsu, N.; Yoshida, Y.; Yamazaki, K.; Nakamura, T.; Dan, S.; Fukui, Y.; Yamori, T. Chemosensitivity profile of cancer cell lines and identification of genes determining chemosensitivity by an integrated bioinformatical approach using cDNA arrays. Mol. Cancer Ther. 2005, 4, 399-412.

102. Weigelt, B.; Hu, Z.; He, X.; Livasy, C.; Carey, L.; Ewend, M.; Glas, A.; Perou, C.; Van't Veer, L. Molecular portraits and 70-gene prognosis signature are preserved throughout the metastatic process of breast cancer. Cancer Res. 2005, 65, 9155-9158.

103. Ioannidis, J.P.; Allison, D.B.; Ball, C.A.; Coulibaly, I.; Cui, X.; Culhane, A.C.; Falchi, M.; Furlanello, C.; Game, L.; Jurman, G.; Mangion, J.; Mehta, T.; Nitzberg, M.; Page, G.P.; Petretto, E.; van Noort, V. Repeatability of published microarray gene expression analyses. Nat. Genet. 2009, 41, 149-155.

104. Chen, X.; Wang, L. Integrating biological knowledge with gene expression profiles for survival prediction of cancer. J. Comput. Biol. 2009, 16, 265-278.

105. Smith, D.D.; Saetrom, P.; Snove, O. Jr.; Lundberg, C.; Rivas, G.E.; Glackin, C.; Larson, G.P. Meta-analysis of breast cancer microarray studies in conjunction with conserved cis-elements suggest patterns for coordinate regulation. BMC Bioinformatics 2008, 9, 63.

106. Lu, X.; Wang, Z.C.; Iglehart, J.D.; Zhang, X.; Richardson, A.L. Predicting featuRes. of breast cancer with gene expression patterns. Breast Cancer Res. Treat. 2008, 108, 191-201.

107. Naderi, A.; Teschendorff, A.E.; Barbosa-Morais, N.L.; Pinder, S.E.; Green, A.R.; Powe, D.G.; Robertson, J.F.; Aparicio, S.; Ellis, I.O.; Brenton, J.D.; Caldas, C. A gene-expression signature to predict survival in breast cancer across independent data sets. Oncogene 2007, 26, 1507-1516.

108. Frkovic-Grazio, S.; Bracko, M. Long term prognostic value of NottinghAm. histological grade and its components in early (pT1N0M0) breast carcinoma. J. Clin. Pathol. 2002, 55, 88-92.

109. Tang, P.; Skinner, K.A.; Hicks, D.G. Molecular classification of breast carcinomas by immunohistochemical analysis: are we ready? Diagn. Mol. Pathol. 2009, 18, 125-132.

110. Nielsen, T.O.; Hsu, F.D.; Jensen, K.; Cheang, M.; Karaca, G.; Hu, Z.; Hernandez-Boussard, T.; Livasy, C.; Cowan, D.; Dressler, L.; Akslen, L.A.; Ragaz, J.; Gown, A.M.; Gilks, C.B.; van de Rijn, M.; Perou, C.M. Immunohistochemical and clinical characterization of the basal-like subtype of invasive breast carcinoma. Clin. Cancer Res. 2004, 10, 5367-5374. 
111. Moyano, J.V.; Evans, J.R.; Chen, F.; Lu, M.; Werner, M.E.; Yehiely, F.; Diaz, L.K.; Turbin, D.; Karaca, G.; Wiley, E.; Nielsen, T.O.; Perou, C.M.; Cryns, V.L. AlphaB-crystallin is a novel oncoprotein that predicts poor clinical outcome in breast cancer. J. Clin. Invest 2006, 116, 261-270.

112. Cheang, M.C.; Chia, S.K.; Voduc, D.; Gao, D.; Leung, S.; Snider, J.; Watson, M.; Davies, S.; Bernard, P.S.; Parker, J.S.; Perou, C.M.; Ellis, M.J.; Nielsen, T.O. Ki67 index, HER2 status, and prognosis of patients with luminal B breast cancer. J. Natl. Cancer Inst. 2009, 101, 736-750.

113. Weigelt, B.; Baehner, F.L.; Reis-Filho, J.S. The contribution of gene expression profiling to breast cancer classification, prognostication and prediction: a retrospective of the last decade. J. Pathol. 2010, 220, 263-280.

114. Dressman, H.K.; Hans, C.; Bild, A.; Olson, J.A.; Rosen, E.; Marcom, P.K.; Liotcheva, V.B.; Jones, E.L.; Vujaskovic, Z.; Marks, J.; Dewhirst, M.W.; West, M.; Nevins, J.R.; Blackwell, K. Gene expression profiles of multiple breast cancer phenotypes and response to neoadjuvant chemotherapy. Clin. Cancer Res. 2006, 12, 819-826.

115. Sorlie, T.; Perou, C.M.; Fan, C.; Geisler, S.; Aas, T.; Nobel, A.; Anker, G.; Akslen, L.A.; Botstein, D.; Borresen-Dale, A.L.; Lonning, P.E. Gene expression profiles do not consistently predict the clinical treatment response in locally advanced breast cancer. Mol. Cancer Ther. 2006, 5, 2914-2918.

116. Lee, J.K.; Coutant, C.; Kim, Y.C.; Qi, Y.; Theodorescu, D.; Symmans, W.F.; Baggerly, K.; Rouzier, R.; Pusztai, L. Prospective comparison of clinical and genomic multivariate predictors of response to neoadjuvant chemotherapy in breast cancer. Clin. Cancer Res. 2010, 16, 711-718.

117. Bauer, J.A.; Chakravarthy, A.B.; Rosenbluth, J.M.; Mi, D.; Seeley, E.H.; De Matos GranjaIngram, N.; Olivares, M.G.; Kelley, M.C.; Mayer, I.A.; Meszoely, I.M.; Means-Powell, J.A.; Johnson, K.N.; Tsai, C.J.; Ayers, G.D.; Sanders, M.E.; Schneider, R.J.; Formenti, S.C.; Caprioli, R.M.; Pietenpol, J.A. Identification of markers of taxane sensitivity using proteomic and genomic analyses of breast tumors from patients receiving neoadjuvant paclitaxel and radiation. Clin. Cancer Res. 2010, 16, 681-690.

118. Osako, T.; Horii, R.; Matsuura, M.; Domoto, K.; Ide, Y.; Miyagi, Y.; Takahashi, S.; Ito, Y.; Iwase, T.; Akiyama, F. High-grade breast cancers include both highly sensitive and highly resistant subsets to cytotoxic chemotherapy. J. Cancer Res. Clin. Oncol. 2010, doi:10.1007/s00432-010-0798-7.

119. Fu, G.; Song, X.C.; Yang, X.; Peng, T.; Wang, Y.; Zhou, G.W. Protein Subcellular Localization Profiling of Breast Cancer Cells by Dissociable Antibody MicroArray (DAMA) Staining. Proteomics 2010, 10, 1536-1544.

120. Isakoff, S.J. Triple-Negative Breast Cancer: Role of Specific Chemotherapy Agents. Cancer J. 2010, 16, 53-61.

121. Seal, M.D.; Chia, S.K. What Is the Difference Between Triple-Negative and Basal Breast Cancers? Cancer J. 2010, 16, 12-16.

122. Venkitaraman, R. Triple-negative/basal-like breast cancer: clinical, pathologic and molecular featuRes. Expert Rev. Anticancer Ther. 2010, 10, 199-207.

123. Perez, E.A.; Moreno-Aspitia, A.; Aubrey Thompson, E.; Andorfer, C.A. Adjuvant therapy of triple negative breast cancer. Breast Cancer Res. Treat. 2010, 120, 285-291. 
124. Schulz, D.M.; Bollner, C.; Thomas, G.; Atkinson, M.; Esposito, I.; Hofler, H.; Aubele, M. Identification of differentially expressed proteins in triple-negative breast carcinomas using DIGE and mass spectrometry. J. Proteome Res. 2009, 8, 3430-3438.

125. Agarwal, R.; Gonzalez-Angulo, A.M.; Myhre, S.; Carey, M.; Lee, J.S.; Overgaard, J.; Alsner, J.; Stemke-Hale, K.; Lluch, A.; Neve, R.M.; Kuo, W.L.; Sorlie, T.; Sahin, A.; Valero, V.; Keyomarsi, K.; Gray, J.W.; Borresen-Dale, A.L.; Mills, G.B.; Hennessy, B.T. Integrative analysis of cyClin. protein levels identifies cyClin. b1 as a classifier and predictor of outcomes in breast cancer. Clin. Cancer Res. 2009, 15, 3654-3662.

126. Rha, S.Y.; Jeung, H.C.; Seo, M.Y.; Kim, S.C.; Yang, W.I.; Moon, Y.W.; Chung, H.C. Prediction of high-risk patients by genome-wide copy number alterations from remaining cancer after neoadjuvant chemotherapy and surgery. Int. J. Oncol. 2009, 34, 837-846.

127. Shadeo, A.; Lam, W.L. Comprehensive copy number profiles of breast cancer cell model genomes. Breast Cancer Res. 2006, 8, R9.

128. Heselmeyer-Haddad, K.; Chaudhri, N.; Stoltzfus, P.; Cheng, J.C.; Wilber, K.; Morrison, L.; Auer, G.; Ried, T. Detection of chromosomal aneuploidies and gene copy number changes in fine needle aspirates is a specific, sensitive, and objective genetic test for the diagnosis of breast cancer. Cancer Res. 2002, 62, 2365-2369.

129. Raphael, B.J.; Volik, S.; Yu, P.; Wu, C.; Huang, G.; Linardopoulou, E.V.; Trask, B.J.; Waldman, F.; Costello, J.; Pienta, K.J.; Mills, G.B.; Bajsarowicz, K.; Kobayashi, Y.; Sridharan, S.; Paris, P.L.; Tao, Q.; Aerni, S.J.; Brown, R.P.; Bashir, A.; Gray, J.W.; Cheng, J.F.; de Jong, P.; Nefedov, M.; Ried, T.; Padilla-Nash, H.M.; Collins, C.C. A sequence-based survey of the complex structural organization of tumor genomes. Genome Biol. 2008, 9, R59.

130. Letessier, A.; Mozziconacci, M.J.; Murati, A.; Juriens, J.; Adelaide, J.; Birnbaum, D.; Chaffanet, M. Multicolour-banding fluorescence in situ hybridization (mbanding-FISH) to identify recurrent chromosomal alterations in breast tumor cell lines. Br. J. Cancer 2005, 92, 382-388.

131. Sigurdsson, S.; Bodvarsdottir, S.K.; Anamthawat-Jonsson, K.; Steinarsdottir, M.; Jonasson, J.G.; Ogmundsdottir, H.M.; Eyfjord, J.E. p53 abnormality and chromosomal instability in the same breast tumor cells. Cancer Genet. Cytogenet. 2000, 121, 150-155.

132. Bozhanov, S.S.; Angelova, S.G.; Krasteva, M.E.; Markov, T.L.; Christova, S.L.; Gavrilov, I.G.; Georgieva, E.I. Alterations in p53, BRCA1, ATM, PIK3CA, and HER2 genes and their effect in modifying clinicopathological characteristics and overall survival of Bulgarian patients with breast cancer. J. Cancer Res. Clin. Oncol. 2010, doi: 10.1007/s00432-010-0824-9.

133. Takahashi, S.; Moriya, T.; Ishida, T.; Shibata, H.; Sasano, H.; Ohuchi, N.; Ishioka, C. Prediction of breast cancer prognosis by gene expression profile of TP53 status. Cancer Sci. 2008, 99, 324-332.

134. Ozcelik, H.; Pinnaduwage, D.; Bull, S.B.; Andrulis, I.L. Type of TP53 mutation and ERBB2 amplification affects survival in node-negative breast cancer. Breast Cancer Res. Treat. 2007, $105,255-265$.

135. Langerod, A.; Zhao, H.; Borgan, O.; Nesland, J.M.; Bukholm, I.R.; Ikdahl, T.; Karesen, R.; Borresen-Dale, A.L.; Jeffrey, S.S. TP53 mutation status and gene expression profiles are powerful prognostic markers of breast cancer. Breast Cancer Res. 2007, 9, R30. 
136. Di Leo, A.; Tanner, M.; Desmedt, C.; Paesmans, M.; Cardoso, F.; Durbecq, V.; Chan, S.; Perren, T.; Aapro, M.; Sotiriou, C.; Piccart, M.J.; Larsimont, D.; Isola, J. p-53 gene mutations as a predictive marker in a population of advanced breast cancer patients randomly treated with doxorubicin or docetaxel in the context of a phase III clinical trial. Ann. Oncol. 2007, 18, 997-1003.

137. Werner, G.; Bartel, M.; Wellinghausen, N.; Essig, A.; Klare, I.; Witte, W.; Poppert, S. Detection of mutations conferring resistance to linezolid in Enterococcus spp. by fluorescence in situ hybridization. J. Clin. Microbiol. 2007, 45, 3421-3423.

138. O'Day, E.; Lal, A. MicroRNAs and their target gene networks in breast cancer. Breast Cancer Res. 2010, 12, 201.

139. Cascio, S.; D'Andrea, A.; Ferla, R.; Surmacz, E.; Gulotta, E.; Amodeo, V.; Bazan, V.; Gebbia, N.; Russo, A. miR-20b modulates VEGF expression by targeting HIF-1alpha and STAT3 in MCF-7 breast cancer cells. J. Cell Physiol. 2010, 224, 242-249.

140. Heneghan, H.M.; Miller, N.; Lowery, A.J.; Sweeney, K.J.; Newell, J.; Kerin, M.J. Circulating microRNAs as novel minimally invasive biomarkers for breast cancer. Ann. Surg. 2010, 251, 499-505.

141. Sempere, L.F.; Christensen, M.; Silahtaroglu, A.; Bak, M.; Heath, C.V.; Schwartz, G.; Wells, W.; Kauppinen, S.; Cole, C.N. Altered MicroRNA expression confined to specific epithelial cell subpopulations in breast cancer. Cancer Res. 2007, 67, 11612-11620.

142. Edwards, P.A. Fusion genes and chromosome translocations in the common epithelial cancers. J. Pathol. 2010, 220, 244-254.

143. Scopelliti, A.; Cammareri, P.; Catalano, V.; Saladino, V.; Todaro, M.; Stassi, G. Therapeutic implications of Cancer Initiating Cells. Expert Opin. Biol. Ther. 2009, 9, 1005-1016.

144. Sakariassen, P.; Immervoll, H.; Chekenya, M. Cancer stem cells as mediators of treatment resistance in brain tumors: status and controversies. Neoplasia 2007, 9, 882-892.

145. Bidlingmaier, S.; Zhu, X.; Liu, B. The utility and limitations of glycosylated human CD133 epitopes in defining cancer stem cells. J. Mol. Med. 2008, 86, 1025-1032.

146. Bertolini, G.; Roz, L.; Perego, P.; Tortoreto, M.; Fontanella, E.; Gatti, L.; Pratesi, G.; Fabbri, A.; Andriani, F.; Tinelli, S.; Roz, E.; Caserini, R.; Lo Vullo, S.; Camerini, T.; Mariani, L.; Delia, D.; Calabro, E.; Pastorino, U.; Sozzi, G. Highly tumorigenic lung cancer CD133+ cells display stemlike featuRes. and are spared by cisplatin treatment. Proc. Natl. Acad. Sci. USA 2009, 106, 16281-16286.

147. Levina, V.; Marrangoni, A.M.; DeMarco, R.; Gorelik, E.; Lokshin, A.E. Drug-selected human lung cancer stem cells: cytokine network, tumorigenic and metastatic properties. PLoS One 2008, 3, e3077.

148. Levina, V.; Marrangoni, A.; Wang, T.; Parikh, S.; Su, Y.; Herberman, R.; Lokshin, A.; Gorelik, E. Elimination of human lung cancer stem cells through targeting of the stem cell factor-c-kit autocrine signaling loop. Cancer Res. 2010, 70, 338-346.

149. Salnikov, A.V.; Gladkich, J.; Moldenhauer, G.; Volm, M.; Mattern, J.; Herr, I. CD133 is indicative for a resistance phenotype but does not represent a prognostic marker for survival of non-small cell lung cancer patients. Int. J. Cancer 2010, 126, 950-958. 
150. Al-Hajj, M.; Wicha, M.; Benito-Hernandez, A.; Morrison, S.; Clarke, M. Prospective identification of tumorigenic breast cancer cells. Proc. Natl. Acad. Sci. USA 2003, 100, 3983-3988.

151. Pece, S.; Tosoni, D.; Confalonieri, S.; Mazzarol, G.; Vecchi, M.; Ronzoni, S.; Bernard, L.; Viale, G.; Pelicci, P.G.; Di Fiore, P.P. Biological and molecular heterogeneity of breast cancers correlates with their cancer stem cell content. Cell 2010, 140, 62-73.

152. Hennessy, B.T.; Gonzalez-Angulo, A.M.; Stemke-Hale, K.; Gilcrease, M.Z.; Krishnamurthy, S.; Lee, J.S.; Fridlyand, J.; Sahin, A.; Agarwal, R.; Joy, C.; Liu, W.; Stivers, D.; Baggerly, K.; Carey, M.; Lluch, A.; Monteagudo, C.; He, X.; Weigman, V.; Fan, C.; Palazzo, J.; Hortobagyi, G.N.; Nolden, L.K.; Wang, N.J.; Valero, V.; Gray, J.W.; Perou, C.M.; Mills, G.B. Characterization of a naturally occurring breast cancer subset enriched in epithelial-to-mesenchymal transition and stem cell characteristics. Cancer Res. 2009, 69, 4116-4124.

153. Silva, F.P.; Swagemakers, S.M.; Erpelinck-Verschueren, C.; Wouters, B.J.; Delwel, R.; Vrieling, H.; van der Spek, P.; Valk, P.J.; Giphart-Gassler, M. Gene expression profiling of minimally differentiated acute myeloid leukemia: M0 is a distinct entity subdivided by RUNX1 mutation status. Blood 2009, 114, 3001-3007.

154. Hicks, M.J.; Mackay, B. Comparison of ultrastructural featuRes. among neuroblastic tumors: maturation from neuroblastoma to ganglioneuroma. Ultrastruct. Pathol. 1995, 19, 311-322.

155. Estrov, Z. Stem cells and somatic cells: reprogramming and plasticity. Clin. Lymphoma Myeloma 2009, 9 (Suppl. 3), S319-S328.

156. Kasemeier-Kulesa, J.; Teddy, J.; Postovit, L.; Seftor, E.; Seftor, R.; Hendrix, M.; Kulesa, P. Reprogramming multipotent tumor cells with the embryonic neural crest microenvironment. Dev. Dyn. 2008, 237, 2657-2666.

157. Postovit, L.; Margaryan, N.; Seftor, E.; Hendrix, M. Role of nodal signaling and the microenvironment underlying melanoma plasticity. Pigment Cell Melanoma Res. 2008, 21, $348-357$.

158. Hendrix, M.; Seftor, E.; Seftor, R.; Kasemeier-Kulesa, J.; Kulesa, P.; Postovit, L. Reprogramming metastatic tumour cells with embryonic microenvironments. Nat. Rev. Cancer 2007, 7, 246-255.

159. Postovit, L.; Costa, F.; Bischof, J.; Seftor, E.; Wen, B.; Seftor, R.; Feinberg, A.; Soares, M.; Hendrix, M. The commonality of plasticity underlying multipotent tumor cells and embryonic stem cells. J. Cell. Biochem. 2007, 101, 908-917.

160. Wang, J.; Rao, S.; Chu, J.; Shen, X.; Levasseur, D.N.; Theunissen, T.W.; Orkin, S.H. A protein interaction network for pluripotency of embryonic stem cells. Nature 2006, 444, 364-368.

161. Taranger, C.; Noer, A.; Sørensen, A.; Håkelien, A.; Boquest, A.; Collas, P. Induction of dedifferentiation, genomewide transcriptional programming, and epigenetic reprogramming by extracts of carcinoma and embryonic stem cells. Mol. Biol. Cell 2005, 16, 5719-5735.

162. Summerer, D.; Schracke, N.; Wu, H.; Cheng, Y.; Bau, S.; Stahler, C.F.; Stahler, P.F.; Beier, M. Targeted high throughput sequencing of a cancer-related exome subset by specific sequence capture with a fully automated microarray platform. Genomics 2010, 95, 241-246.

163. Roukos, D.H. Novel clinico-genome network modeling for revolutionizing genotype-phenotypebased personalized cancer care. Expert Rev. Mol. Diagn. 2010, 10, 33-48. 
164. Huang, Y.W.; Huang, T.H.; Wang, L.S. Profiling DNA methylomes from microarray to genomescale sequencing. Technol. Cancer Res. Treat. 2010, 9, 139-147.

165. Bell, D.W. Our changing view of the genomic landscape of cancer. J. Pathol. 2010, 220, 231-243.

166. Aparicio, S.A.; Huntsman, D.G. Does massively parallel DNA resequencing signify the end of histopathology as we know it? J. Pathol. 2010, 220, 307-315.

167. Shah, S.P.; Morin, R.D.; Khattra, J.; Prentice, L.; Pugh, T.; Burleigh, A.; Delaney, A.; Gelmon, K.; Guliany, R.; Senz, J.; Steidl, C.; Holt, R.A.; Jones, S.; Sun, M.; Leung, G.; Moore, R.; Severson, T.; Taylor, G.A.; Teschendorff, A.E.; Tse, K.; Turashvili, G.; Varhol, R.; Warren, R.L.; Watson, P.; Zhao, Y.; Caldas, C.; Huntsman, D.; Hirst, M.; Marra, M.A.; Aparicio, S. Mutational evolution in a lobular breast tumor profiled at single nucleotide resolution. Nature 2009, 461, 809-813.

168. Reis-Filho, J.S. Next-generation sequencing. Breast Cancer Res. 2009, 11 (Suppl. 3), S12.

169. Morrissy, A.S.; Morin, R.D.; Delaney, A.; Zeng, T.; McDonald, H.; Jones, S.; Zhao, Y.; Hirst, M.; Marra, M.A. Next-generation tag sequencing for cancer gene expression profiling. Genome Res. 2009, 19, 1825-1835.

170. Mardis, E.R.; Wilson, R.K. Cancer genome sequencing: a review. Hum Mol. Genet 2009, 18, R163-R168.

171. Mardis, E.R. New strategies and emerging technologies for massively parallel sequencing: applications in medical research. Genome Med. 2009, 1, 40.

172. Levin, J.Z.; Berger, M.F.; Adiconis, X.; Rogov, P.; Melnikov, A.; Fennell, T.; Nusbaum, C.; Garraway, L.A.; Gnirke, A. Targeted next-generation sequencing of a cancer transcriptome enhances detection of sequence variants and novel fusion transcripts. Genome Biol. 2009, 10, R115.

173. Kato, K. Impact of the next generation DNA sequencers. Int. J. Clin. Exp Med. 2009, 2, 193-202.

174. Salehi-Ashtiani, K.; Yang, X.; Derti, A.; Tian, W.; Hao, T.; Lin, C.; Makowski, K.; Shen, L.; Murray, R.R.; Szeto, D.; Tusneem, N.; Smith, D.R.; Cusick, M.E.; Hill, D.E.; Roth, F.P.; Vidal, M. Isoform discovery by targeted cloning, 'deep-well' pooling and parallel sequencing. Nat. Methods 2008, 5, 597-600.

175. Morozova, O.; Marra, M.A. From cytogenetics to next-generation sequencing technologies: advances in the detection of genome rearrangements in tumors. Biochem. Cell Biol. 2008, 86, 81-91.

176. Morozova, O.; Marra, M.A. Applications of next-generation sequencing technologies in functional genomics. Genomics 2008, 92, 255-264.

177. Marguerat, S.; Wilhelm, B.T.; Bahler, J. Next-generation sequencing: applications beyond genomes. Biochem. Soc. Trans. 2008, 36, 1091-1096.

178. Kobel, M.; Gilks, C.B.; Huntsman, D.G. Adult-type granulosa cell tumors and FOXL2 mutation. Cancer Res. 2009, 69, 9160-9162.

179. Schrader, K.A.; Gorbatcheva, B.; Senz, J.; Heravi-Moussavi, A.; Melnyk, N.; Salamanca, C.; Maines-Bandiera, S.; Cooke, S.L.; Leung, P.; Brenton, J.D.; Gilks, C.B.; Monahan, J.; Huntsman, D.G. The specificity of the FOXL 2 c. $402 \mathrm{C}>\mathrm{G}$ Somatic mutation: a survey of solid tumors. PLoS One 2009, 4, e7988. 
180. Shah, S.P.; Kobel, M.; Senz, J.; Morin, R.D.; Clarke, B.A.; Wiegand, K.C.; Leung, G.; Zayed, A.; Mehl, E.; Kalloger, S.E.; Sun, M.; Giuliany, R.; Yorida, E.; Jones, S.; Varhol, R.; Swenerton, K.D.; Miller, D.; Clement, P.B.; Crane, C.; Madore, J.; Provencher, D.; Leung, P.; DeFazio, A.; Khattra, J.; Turashvili, G.; Zhao, Y.; Zeng, T.; Glover, J.N.; Vanderhyden, B.; Zhao, C.; Parkinson, C.A.; Jimenez-Linan, M.; Bowtell, D.D.; Mes-Masson, A.M.; Brenton, J.D.; Aparicio, S.A.; Boyd, N.; Hirst, M.; Gilks, C.B.; Marra, M.; Huntsman, D.G. Mutation of FOXL2 in granulosa-cell tumors of the ovary. N. Engl. J. Med. 2009, 360, 2719-2729.

(C) 2010 by the authors; licensee MDPI, Basel, Switzerland. This article is an Open Access article distributed under the terms and conditions of the Creative Commons Attribution license (http://creativecommons.org/licenses/by/3.0/). 